\title{
DENTAL HEALTH SERVICE DURING PANDEMIC COVID-19 : A LITERATURE REVIEW
}

Nabila Rizkika*, Sakundarno Adi**

${ }^{*}$ Magister Epidemiologi, Sekolah Pascasarjana Universitas Diponegoro, Semarang

${ }^{*}$ Bagian Epidemiologi Fakultas Kesehatan Masyarakat Universitas Diponegoro, Semarang

Correspondence: nabilarizkika@gmail.com

\section{Keywords:}

COVID-19; dental health service; infection control

\section{ABSTRACT}

Background: COVID-19 pandemic is a new challenge for dentist. Doctor-patients contact, aerosol formed during treatment, and contact with contaminated instruments are the transmission route for COVID19 infection. Several guidelines and suggestion regarding infection control measures have been released, but the standard protective measures in daily clinical work are not effective enough to prevent the spread of COVID-19. Aim To provide an overview of the measures that can be made in order to prevent the spread of COVID-19 in dental health services

Method: Systematic literature review used literature search methods in electronic databases: Google Scholar, Science Direct, and PubMed. The keywords were "COVID-19 and dental practice" and "dental practice during COVID-19". The inclusion criteria for selection of scientific articles were years of publication from January 2020 to October 2020, published in English and full paper available. Out of 44 articles that have been screened, nine articles have been included in this review

Result: The nine articles that were collected have already pointed out some necessary measures. Patients screening and triage are the first steps in selecting emergency cases, minimal invasive procedure are the principle in every dental treatment, and the use or personal protective equipment for dentist and team is an absolute requirement before performing any dental treatment.

Conclusion: Protecting the oral environment through dental checksup with preventive measure is important during the pandemic. 


\section{PENDAHULUAN}

Desember 2019 dunia dikejutkan dengan adanya pelonjakan kejadian pneumonia di Wuhan yang belum diketahui penyebabnya dan secara cepat menyebar di kota-kota lain di Cina'. Pathogen penyebab kasus tersebut diidentifikasi berasal dari keluarga coronavirus yang penyakitnya kemudian dikenal dengan nama Corona Virus Disease (COVID-19)2. Virus ini berkembang pesat dan tidak terkontrol di seluruh penjuru dunia yang kemudian pada 11 Maret 2020 WHO mengumumkan COVID19 sebagai pandemi global ${ }^{3}$. Kasus COVID-19 pertama kali muncul di Indonesia pada 2 Maret 2020 tepatnya di Depok, Jawa Barat ${ }^{4}$. Sebanyak 282.724 kasus telah terkonfirmasi di Indonesia hingga September 2020, dengan mortality rate sebesar 3,7\% (10.601 kasus) $)^{5}$.

COVID-19 dapat menular melalui droplets bahkan penelitian terbaru menyebutkan penularannya bisa terjadi melalui airborne'. Pada bulan Mei 2020 Ikatan Dokter Indonesia mengumumkan sebanyak 25 dokter dan 6 dokter gigi telah meninggal selama pandemi karena infeksi penyakit COVID-195. Tenaga kesehatan berada dalam kondisi yang berisiko tinggi untuk tertular termasuk dokter gigi juga berisiko tinggi tertular COVID-19 karena terpapar langsung dengan saliva maupun darah ${ }^{6}$. Peralatan kedokteran gigi seperti handpiece, air-water syringe, ultrasonic scaler dapat menghasilkan aerosol yang banyak, oleh karenanya berpotensi tinggi mempermudah penyebaran virus dari pasien ke dokter gigi dan asisten gigi ataupun sebaliknya7. SARS-CoV-2 dapat tetap hidup di aerosol setidaknya selama 3 jam dan dapat bertahan di permukaan benda mati selama lebih dari 72 jam,6,8,9.
Pada Maret 2020 awal pandemi terjadi American Dental Association (ADA) merekomendasikan kepada dokter gigi di seluruh dunia untuk menunda tindakan kedokteran gigi elektif selama 3 minggu ${ }^{10,11}$, ADA juga memberikan pedoman tentang kondisi yang perlu dipertimbangkan sebagai perawatan gigi darurat maupun non darurat ${ }^{11}$. Seiring dengan pandemi yang belum bisa diprediksi berakhir dan kebutuhan akan perawatan gigi yang tidak bisa di tunda, tindakan perlindungan standar dalam pelayanan gigi tidak cukup efektif untuk mencegah penyebaran COVID-19. Literatur yang membahas tentang upaya pencegahan COVID-19 pada praktik gigi masih belum banyak ditemukan di Indonesia. Tujuan dari studi literatur ini adalah untuk memberikan gambaran tentang upaya-upaya yang dapat dilakukan dalam rangka pencegahan penyebaran COVID-19 pada pelayanan kedokteran gigi.

\section{METODE PENELITIAN}

Penelusuran literatur dilakukan dengan mencari artikel / jurnal dari kajian pustaka di database PubMed, Sciencedirect, dan Google Scholar. Kata kunci berikut digunakan dalam pencarian sumber "COVID-19 and dental practice" atau "dental practice during COVID19". Semua artikel dari Januari 2020 hingga Oktober 2020 yang memenuhi kriteria seleksi sebagai rekomendasi atau pedoman dalam praktik gigi selama masa pandemic COVID-19 diambil. Artikel yang dianggap tidak relevan, di terbitkan sebelum pandemi COVID-19, atau berdasarkan opini tanpa bukti pendukung akan dikecualikan. Kriteria inklusi dalam penelitian ini sebagai berikut: (1) artikel berbahasa Inggris dan Indonesia yang diterbitkan pada Januari 
2020 hingga Oktober 2020, (2) studi desain penelitian berupa literature review tentang pedoman praktik gigi secara umum yang membahas pengaturan pasien, tempat praktik, prosedur sebelum perawatan, selama perawatan, dan sesudah perawatan serta tidak terpusat pada satu cabang ilmu kedokteran gigi tertentu. Sebanyak 48 artikel yang teridentifikasi melalui pencarian kata kunci tersebut. Selanjutnya menghapus artikel yang berulang atau duplikasi sebanyak 4 artikel. Kemudian sebanyak 44 artikel dilakukan skrining. Hasilnya sebanyak 9 artikel yang terinklusi untuk dilakukan review.

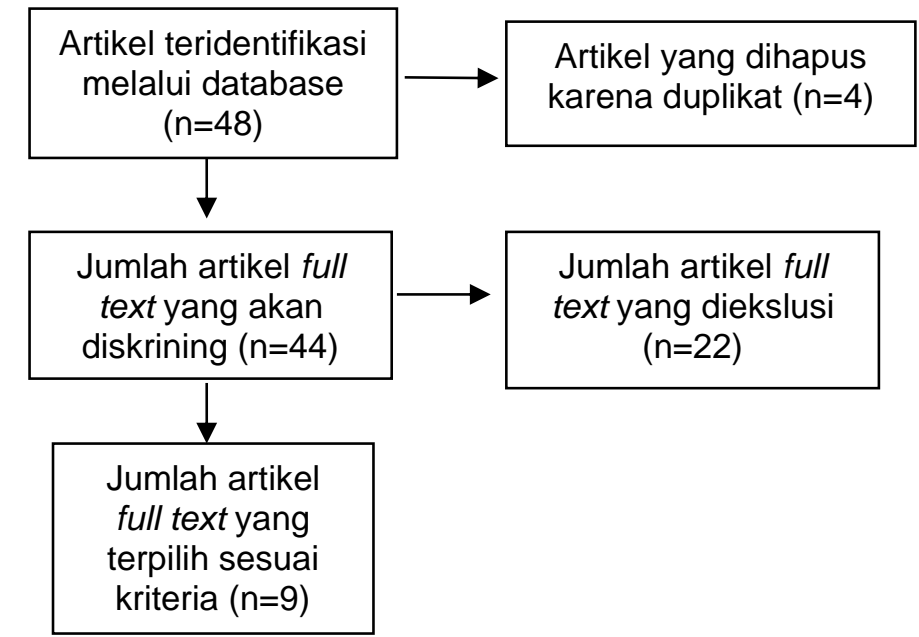

Gambar 1. Alur Pemilihan Artikel/Jurnal Penelitian

\section{HASIL PENELITIAN}

Review ini menggunakan hasil penelitian dari berbagai negara mengenai pedoman praktik dokter gigi pada masa pandemic COVID-19. Dari 48 artikel yang ditemukan melalui 3 database, sebanyak 9 artikel penelitian yang terpilih untuk dilakukan review. Karakteristik 7 artikel yang terpilih sebagian besar menggunakan desain literature review.

Tabel 1. Pedoman Praktik Dokter Gigi Berdasarkan Artikel Pilihan

\begin{tabular}{|c|c|c|c|}
\hline No & $\begin{array}{c}\text { Penulis dan Tahun } \\
\text { Terbit }\end{array}$ & Judul & Pedoman yang Direkomendasikan \\
\hline 1 & $\begin{array}{l}\text { Abrahamovitz dkk } \\
\qquad(2020)\end{array}$ & $\begin{array}{l}\text { Dental care during the } \\
\text { coronavirus disease } 2019 \\
\text { (COVID-19) outbreak: } \\
\text { operatory considerations and } \\
\text { clinical aspects }\end{array}$ & $\begin{array}{l}\text { - Pasien yang datang tidak } \\
\text { diperkenankan didampingi keluarga } \\
\text { selama di ruang perawatan. Satu } \\
\text { pendamping di ijinkan pada pasien }\end{array}$ \\
\hline
\end{tabular}


dibawah umur atau pasien yang

berkebutuhan khusus

- Skrining pasien melalui telepon (telescreening), triase pasien saat sudah tiba di tempat praktik

- Prosedur perawatan:

$\checkmark$ Antibiotik profilaksis pada pasien suspek/konfirmasi

Covid-19 sebelum perawatan

$\checkmark$ Berkumur sebelum perawatan

$\checkmark$ Penggunaan rubber dam dan extra high volume suction

2 Alharabi dkk (2020) Guidelines for Dental Care • Penggunaan terapi menggunakan Provision during The COVID- Ibuprofen harus di hindari

19 Pandemic

- Prosedur perawatan:

$\checkmark$ Screening melalui tele-screening

$\checkmark$ Berkumur dengan povidone iodine $0,23 \%$ selama 15 detik

$\checkmark$ Penggunaan rubber dam

$\checkmark$ Instrument sekali pakai lebih diutamakan untuk digunakan

$\checkmark$ Prosedur yang menghasilkan aerosol sebisa mungkin dihindari

3 Amato dkk (2020) Infection Control in Dental - Perawatan pada pasien geriatri Practice during The Covid-19 dengan penyakit penyerta dilakukan Pandemic pada pagi hari

- Pasien menggunakan APD pada saat prosedur perawatan

- Pedoman perawatan:

$\checkmark$ Teledentistry untuk mengetahui riwayat perjalanan pasien

$\checkmark$ Berkumur dengan hydrogen peroxide $1 \%$, pengunaan chlorhexidine tidak disarankan

$\checkmark$ Penggunaan hand piece tanpa anti retraksi dan air-water syringes dibatasi

$\checkmark$ Isolasi menggunakan rubber dam 


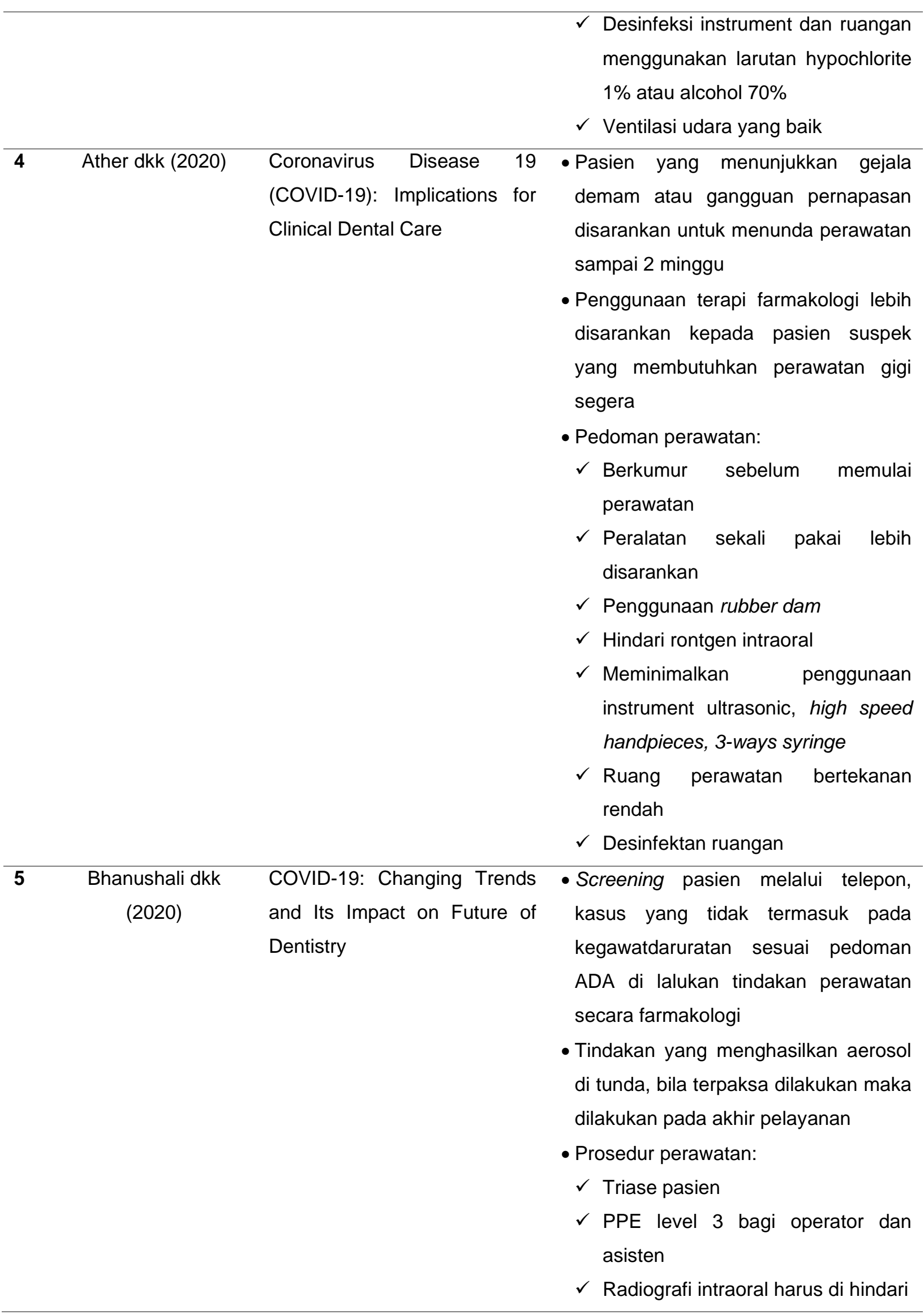




\begin{tabular}{|c|c|c|c|}
\hline & & & $\begin{array}{l}\checkmark \text { Desinfeksi seluruh ruangan } \\
\text { menggunakan sodium hypochlorite } \\
1 \% \\
\checkmark \text { Teledentistry terhadap semua } \\
\text { pasien yang sudah melakukan } \\
\text { perawatan untuk memantau } \\
\text { perkembangan perawatan }\end{array}$ \\
\hline & $\begin{array}{l}\text { Gurzawska-Comis } \\
\text { dkk (2020) }\end{array}$ & $\begin{array}{l}\text { Recommendations for Dental } \\
\text { Care during COVID-19 } \\
\text { Pandemic }\end{array}$ & $\begin{array}{l}\text { - Pedoman perawatan: } \\
\checkmark \text { Triase pasien } \\
\checkmark \text { Penggunaan masker N95 untuk } \\
\text { pasien risiko tinggi Covid-19, } \\
\text { masker bedah kombinasi face- } \\
\text { shield untuk pasien dengan risiko } \\
\text { rendah } \\
\checkmark \text { Desinfeksi dan ventilasi yang baik di } \\
\text { ruang perawatan } \\
\checkmark \text { Berkumur dengan povidone iodine } \\
0,2 \% \text { atau hydrogen peroxide 1- } \\
1,5 \% \text {. Chlorhexidine } 0,1 \% \text { dan } 0,2 \% \\
\text { tanpa tambahan alcohol tidak efektif } \\
\text { untuk melawan virus }\end{array}$ \\
\hline 7 & Passarelli dkk (2020) & $\begin{array}{l}\text { The Impact of The COVID-19 } \\
\text { Infection in Dentistry }\end{array}$ & $\begin{array}{l}\text { - Klasifikasi pasien berdasarkan risiko } \\
\text { penularan, menjadi pasien risiko } \\
\text { rendah, risiko sedang, risiko tinggi } \\
\text { - Pasien risiko sedang sebaiknya } \\
\text { dilakukan penundaan perawatan } \\
\text { sampai } 14 \text { hari. Jika tidak dapat di } \\
\text { tunda, perawatan dilakukan pada akhir } \\
\text { jam pelayanan. } \\
\text { - Pasien risiko tinggi tidak diperbolehkan } \\
\text { melakukan perawatan. }\end{array}$ \\
\hline 8 & Peng dkk (2020) & $\begin{array}{l}\text { Transmission routes of 2019- } \\
\mathrm{nCoV} \text { and controls in dental } \\
\text { practice }\end{array}$ & $\begin{array}{l}\text { - Pedoman perawatan: } \\
\checkmark \text { Evaluasi riwayat perjalanan pasien } \\
\checkmark \text { Berkumur dengan bahan oksidatif } \\
\text { seperti povidone iodine } 0,2 \% \text { dan } \\
\text { hydrogen peroxide } 1 \% \text { terutama } \\
\text { pada perawatan yang tidak bisa } \\
\text { menggunakan rubber dam }\end{array}$ \\
\hline
\end{tabular}




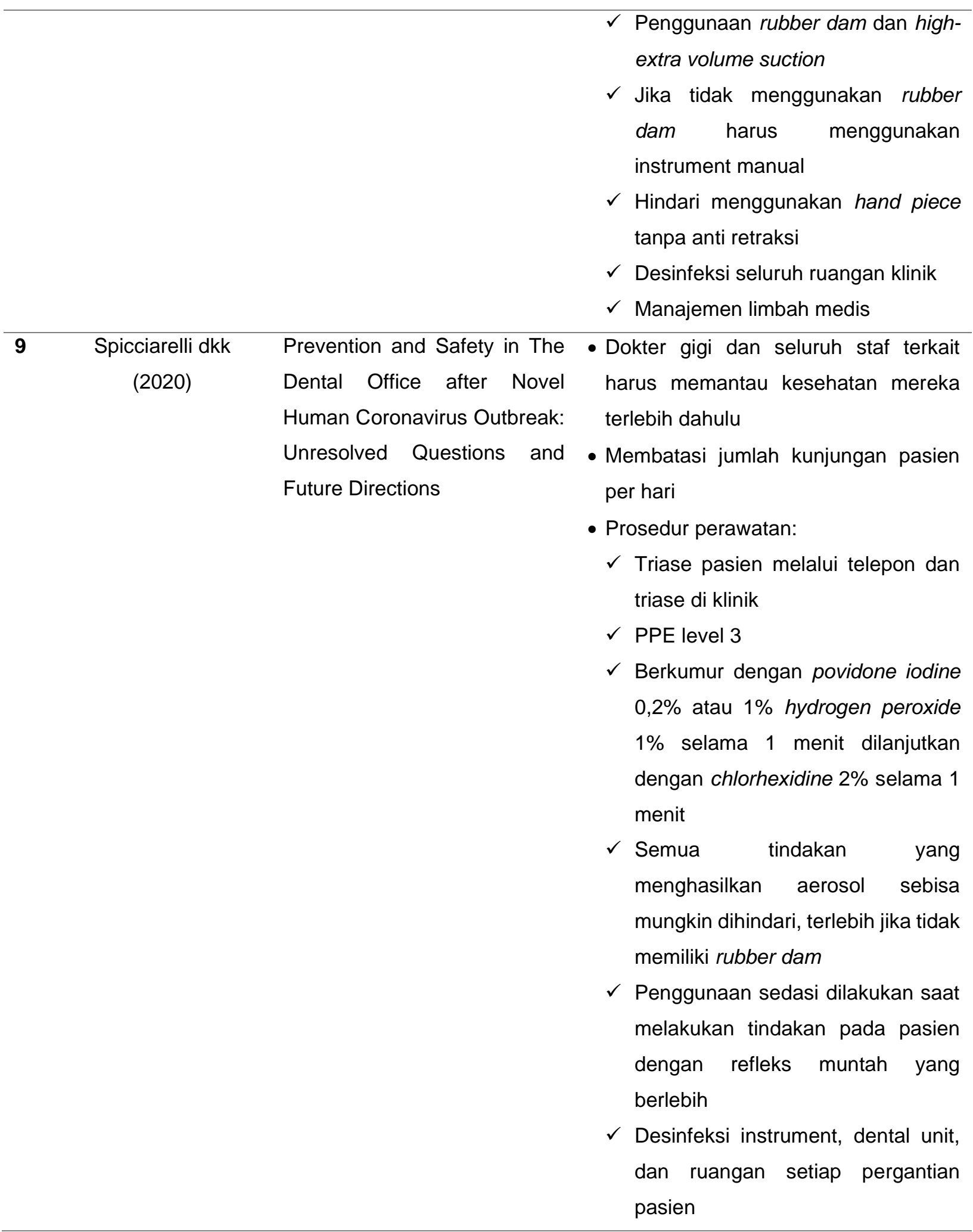

PEMBAHASAN

\section{Transmisi di Praktik Gigi}

Penelitian To dkk menyebutkan bahwa SARS-CoV-2 dapat mengikat reseptor angiotension-converting enxyme 2 (ACE2) ${ }^{12}$. Reseptor ACE2 banyak terdapat di permukaan sel epitel mukosa di rongga hidung, nasofaring, mukosa mulut, mata dan lidah ${ }^{10}$. Dengan demikian, saliva sebagai cairan yang melumasi 
permukaan mukosa rongga mulut menjadi sumber utama infeksi COVID-1912.

Penularan COVID-19 di tempat praktik gigi terjadi melalui empat jalur: (1) paparan langsung dari sekret pernapasan yang mengandung saliva, droplets, atau darah dari pasien terkonfirmasi, (2) kontak dengan permukaan/instrument yang terkontaminasi, (3) airborne, (4) kontak mukosa (hidung, mulut) dengan droplets dan aerosol yang terkontaminasi yang dihasilkan dari batuk/berbicara tanpa menggunakan masker ${ }^{13}$. Pada ruang praktik gigi prosedur perawatan menggunakan high-speed handpiece atau instrument ultrasonic dapat menghasilkan aerosol yang ketika bercampur dengan cairan dalam rongga mulut seperti darah dan saliva, bioaerosol terbentuk ${ }^{14,15}$. Bioaerosol biasanya terkontaminasi oleh bakteri, jamur, virus dan berpotensi menyebar di udara dalam waktu yang cukup lama sehingga bisa terhirup oleh dokter gigi atau pasien ${ }^{15}$. Aerosol dan droplets yang terbentuk selama prosedur gigi dapat menempel pada permukaan dan instrument gigi sehingga meningkatkan potensi penularan dari kontaminasi tersebut ${ }^{16,17}$. Dokter gigi merupakan salah satu pekerjaan paling berisiko terhadap infeksi SARS-COV-2 dan adanya kebijakan prosedur terhadap manajemen pasien dan perawatan sangat penting dilakukan untuk mitigasi risiko COVID$19^{18}$

\section{Pra Perawatan}

Penutupan praktik dokter gigi bisa dilakukan untuk mengurangi jumlah orang yang terinfeksi, namun akan meningkatkan jumlah pasien dengan kebutuhan perawatan gigi ${ }^{19}$. Pembatasan jumlah pasien dapat dilakukan sebagai langkah awal pencegahan penularan COVID-199. Strategi untuk meminimalkan kontak dengan pasien adalah dengan melakukan screening melalui media komunikasi seperti telepon (tele-screening) ${ }^{11}$. Menurut Dedy dkk screening pasien harus dilakukan dalam dua tahap, yaitu screening awal (tele-screening) dan screening pra perawatan ${ }^{10}$. Tele-screening dilakukan untuk mengetahui status risiko COVID-19 dan perawatan yang sesuai dengan kondisi pasien ${ }^{14}$. Pertanyaan yang diajukan saat telescreening antara lain adanya gejala seperti demam, batuk dan sesak napas, riwayat kontak dengan pasien/suspek kasus COVID-19, serta riwayat perjalanan ke daerah dengan insidensi COVID-19 tinggi6,9,20,21. Pada saat di tempat praktik gigi dilakukan screening pra perawatan dengan cara mengisi kuesioner tentang riwayat medis dan COVID-19 serta keluhan permasalah gigi10,22. Pengecekan suhu tubuh juga dilakukan ${ }^{10,18,23}$. Pada pasien dengan risiko medium / mengalami gejala demam dan gangguan saluran pernapasan, harus menunda perawatan sampai 14 hari 6,14. Jika perawatan tidak dapat ditunda maka prosedur perawatan sebaiknya dilakukan di ruangan bertekanan negatif pada akhir jam pelayanan ${ }^{6,11,18}$.

Pada area ruang tunggu dilengkapi dengan poster instruksi tentang cuci tangan, etika batuk, dan aturan social distancing yang dipasang di pintu masuk dan di tempat strategis yang terlihat oleh pasien dengan menggunakan bahasa yang mudah dipahami ${ }^{21}$. Barangbarang seperti majalah, koran, mainan tidak diperkenan ada di ruang tunggu karena dapat berperan sebagai media kontaminasi COVID1911,24. Pasien tidak diijinkan membawa pendamping, satu pendamping diperkenankan bagi pasien dibawah umur atau berkebutuhan khusus ${ }^{11}$. 


\section{Prosedur Perawatan}

Sebelum melakukan prosedur perawatan, dokter gigi dan asisten diwajibkan Selama prosedur perawatan dokter gigi maupun asisten diwajibkan untuk memakai alat pelindung diri (APD) level 3 yang meliputi sarung tangan, gaun/baju coverall, penutup kepala, penutup sepatu, pelindung mata termasuk kacamata atau pelindung wajah sekali pakai/dapat digunakan kembali yang menutupi bagian depan dan samping wajah, dan respirator N954 atau tingkat yang lebih tinggi 19,21,25. Kombinasi masker bedah dan pelindung wajah penuh dapat digunakan dalam situasi di mana respirator tidak tersedia 21 .

Dokter gigi dan asisten harus mencuci tangan dengan langkah dan waktu yang benar guna mencegah penularan COVID-19 14,24,26. Waktu mencuci tangan yang benar adalah sebelum memeriksa pasien, sebelum melakukan prosedur perawatan gigi, setelah menyentuh pasien, setelah menyentuh lingkungan dan peralatan tanpa desinfeksi, dan setelah menyentuh mukosa mulut, darah, kulit yang luka ${ }^{23,25}$. Hand rubs berbasis alkohol dengan konsentrasi $70-90 \%$ lebih efektif digunakan untuk membunuh bakteri dan virus ${ }^{14}$.

Penggunaan obat kumur dapat mengurangi mikroba dalam rongga mulut ${ }^{27}$. Menurut temuan Ather dkk berkumur dengan 11,5\% hidrogen peroksida selama 1 menit berfungsi untuk aktivitas virucidal nonspesifik melawan virus, sedangkan povidone iodine $0,2 \%$ selama 1 menit direkomendasikan karena dapat mengurangi virus corona dalam saliva ${ }^{14}$. Spicciarelli dkk menyarankan sebelum memulai perawatan pasien sebaiknya berkumur dengan povidone iodine $0,2 \%$ atau hydrogen peroksida $1 \%$ selama 1 menit dan dilanjutkan dengan chlorhexidine $2 \%$ selama 1 menit $^{20}$. Menurut Gurzawska-comis dan didukung Banakar, penggunaan chlorhexidine tidak disarankan sebagai obat kumur untuk pencegahan coronavirus namun chlorhexidine dengan tambahan alcohol masih bisa digunakan ${ }^{26,28}$. Meskipun belum ada penelitian lebih lanjut tentang berapa lama efek antivirus dari obat kumur dapat bertahan, namun berkumur sebelum prosuder perawatan dimulai dapat dilakukan sebagai upaya preventif penularan COVID-1923,27

Rubber dam dan high extra suction harus selalu digunakan dalam setiap tindakan perawatan gigi11,14,24. Rubber dam secara signifikan bisa mengurangi partikel di udara hingga $70 \%^{29}$. Penggunaan instrument yang menghasilkan aerosol sebaiknya dihindari digantikan dengan instrument tangan seperti alat scaling manual atau ekskavator yang dikombinasikan dengan bahan penghilang karies chemomechanical seperti natrium hypoklorit $(\mathrm{NaOCl})^{8,14,19}$. Posisi operator saat tindakan sebaiknya dilakukan dalam posisi jam 10 atau 11, posisi jam 8 harus dihindari, untuk menghindari percikan yang terjadi saat prosedur perawtan gigi dan bekerja dengan teknik four handed ${ }^{21,27,30,31}$. Penggunaan handpiece tanpa fungsi anti-retraksi harus di hindari20,23,24. Prosedur radiografi intra-oral dapat menstimulasi sekresi saliva sehingga harus di hindari ${ }^{20}$. Oleh karenanya penggunaan radiografi extra oral seperti panoramic dan CBCT lebih disarankan27. Penggunaan anastesi teknik sedasi dapat menjadi pilihan pada pasien dengan refleks muntah yang berlebihan ${ }^{20}$. Pada tindakan bedah penggunaan suturing resorbable lebih disarankan untuk mengurangi kunjungan ke praktik gigi30. 


\section{Pasca Perawatan}

Prosedur dekontaminasi dan desinfeksi, instrument sesuai pedoman dalam kedokteran gigi masih efektif untuk mengurangi risiko penularan COVID-1932. Natrium hipoklorit 0,5\% dapat digunakan untuk desinfeksi permukaan yang terkena darah/pus ${ }^{29}$. Larutan desinfeksi harus dipergunakan sesuai instruksi pabrik, apabila larutan terlalu encer proses desinfeksi menjadi tidak efektif namun jika larutan terlalu pekat bisa agresif ke permukaan instrument ${ }^{20}$. Lampu Ultraviolet-C (UV-C) dapat dijadikan alterfatif untuk desinfeksi ruangan karena tidak meninggaolkan bekas residu setelah digunakan juga memiliki sprektrum luas dengan waktu yang relative singkat ${ }^{29}$.

Menurut Amato dkk dan Bhanusli desinfeksi instrument dan ruangan dapat dilakukan dengan menggunakan natrium hipoklorit ${ }^{21,24}$. Penelitian yang dilakukan oleh Kampf dkk menemukan beberapa desinfektan yang efektif terhadap beberapa jenis coronavirus, diantaranya etanol 78-95\%, 2propanol 70-100\%, kombinasi 45\% 2-propanol dan $30 \% 1$-propanol, formaldehyde $0,7-1 \%$, povidone iodine $0,23 \%-7,5 \%$, hidrogen peroksida $0,5 \%{ }^{33}$. Pedoman WHO terbaru menyebutkan bahwa kombinasi air, deterjen dan bahan desinfektan (1:50) efektif untuk SARS-CoV-20.

Pada awal pandemic dianjurkan untuk mengurangi penggunaan ibuprofen dan golongan NSAID pada pasien positif dikarenakan adanya peningkatan angiotensin converting enzyme 2 (ACE-2) yang dapat memperburuk gejala COVID-19, namun kemudian WHO mencabut larangan tersebut karena kurangnya bukti ilmiah. Penggunaan paracetamol lebih disarankan diberikanan untuk penanganan nyeri34.
Rongga mulut merupakan area berisiko tinggi yang potensial sebagai jalur penularan SARS-Cov-2, dengan menjaga lingkungan rongga mulut dapat membantu mencegah infeksi COVID-1935. Pemeriksaan gigi secara rutin tetap perlu dilakukan selama masa pandemic, baik untuk mencegah infeksi COVID-19 juga untuk mencegah terjadinya penurunan fungsi rongga mulut secara dini ${ }^{36}$.

\section{Kesimpulan}

Prosedur perawatan di praktik dokter gigi berpotensi sebagai jalur transmisi COVID-19. Penularan dapat terjadi melalui kontak langsung dokter-pasien, aerosol yang terbentuk selama prosedur perawatan, juga kontaminasi dari instrument atau permukaan di ruang praktik dokter gigi. Penundaan perawatan gigi selama masa pandemi tidak serta menjadi jawaban untuk mengurangi risiko penularan. Melindungi lingkungan rongga mulut melalui pemeriksaan gigi secara teratur dan pembersihan dengan tindakan preventif penting dilakukan selama masa pandemi. Berbagai literatur yang dikumpulkan memberikan rekomendasi protocol yang harus dilakukan dalam usaha pengendalian dan pencegahan infeksi COVID-19 di praktik dokter gigi. Upaya tersebut dapat dilakukan dengan cara berikut: (1) manajemen pasien melalui screening dan penilaian risiko, (2) pencegahan infeksi sebelum tindakan dengan tindakan preventif pasien dan penggunaan alat pelindung diri bagi dokter gigi dan tim, (3) tindakan pencegahan selama prosedur perawatan, (4) desinfeksi. 


\section{DAFTAR PUSTAKA}

1. Peditto, M., Scapellato, S., Marcianò, A., Costa, P. \& Oteri, G. Dentistry during the covid-19 epidemic: An italian workflow for the management of dental practice. Int. J. Environ. Res. Public Health 17, (2020).

2. Ataş, O. \& Yildirim, T. T. Evaluation of knowledge, attitudes, and clinical education of dental students about COVID-19 pandemic. PeerJ 8, (2020).

3. Susilo, A. et al. Coronavirus Disease 2019: Tinjauan Literatur Terkini. J. Penyakit Dalam Indones. 7, 45 (2020).

4. Kementerian Kesehatan Indonesia. Dashboard Kasus COVID-19 di Indonesia. https://www.kemenkes.go.id/article/view/20 031900002/Dashboard-Data-KasusCOVID-19-di-Indonesia.httml (2020).

5. Satuan Tugas Penanganan Covid-19. Peta Sebaran. https://covid19.go.id/peta-sebaran (2020).

6. Passarelli, P. C., Rella, E., Manicone, P. F., Garcia-Godoy, F. \& D'Addona, A. The impact of the COVID-19 infection in dentistry. Exp. Biol. Med. 245, 940-944 (2020).

7. Al-Nerabiah, Z., Alkhouli, M., Laflouf, M. \& Abdul-Hak, M. Pediatric dentists consideration for Covid-19 in children: Review article. $\sim 628 \sim$ Int. J. Appl. Dent. Sci. 6, 628-630 (2020).

8. Hudyono, R. et al. During and post COVID19 pandemic: prevention of cross infection at dental practices in country with tropical climate. Dent. J. Maj. Kedokt. Gigi 53, 8187 (2020).

9. Liasari, I. \& Lesmana, H. Studi Literatur: Pencegahan Penyebaran SARS-CoV-2 Pada Praktik Kedokteran Gigi. Media Kesehat. Gigi 19, 41-46 (2020).

10.Dedy, H. et al. Dealing with the high-risk potential of COVID-19 cross-infection in dental practice. Maj. Kedokt. Gigi Indones. 6 , 1-15 (2020).

11. Abramovitz, I. et al. Dental care during the coronavirus disease 2019 (COVID-19) outbreak: operatory considerations and clinical aspects. Quintessence Int. 51, 418429 (2020).

12. To, K. K. W. et al. Consistent detection of 2019 novel coronavirus in saliva. Clin. Infect. Dis. 71, 841-843 (2020).

13.Fallahi, H. R., Keyhan, S. O., Zandian, D., Kim, S.-G. \& Cheshmi, B. Being a front-line dentist during the Covid-19 pandemic: a literature review. Maxillofac. Plast. Reconstr. Surg. 42, (2020).

14.Ather, A., Patel, B., Ruparel, N. B., Diogenes, A. \& Hargreaves, K. M. Coronavirus Disease 19 (COVID-19): Implications for Clinical Dental Care. J. Endod. 46, 584-595 (2020). 15.Ge, Z. yu, Yang, L. ming, Xia, J. jia, Fu, X. hui \& Zhang, Y. zhen. Possible aerosol transmission of COVID-19 and special precautions in dentistry. J. Zhejiang Univ. Sci. B 21, 361-368 (2020).

16. Sinjari, B. et al. The impact of covid-19 related lockdown on dental practice in central italy-outcomes of a survey. Int. J. Environ. Res. Public Health 17, 1-14 (2020).

17. Izzetti, R., Nisi, M., Gabriele, M. \& Graziani, F. COVID-19 Transmission in Dental Practice: Brief Review of Preventive Measures in Italy. J. Dent. Res. 99, 10301038 (2020).

18. Lee, Y. L. et al. Dental care and infectioncontrol procedures during the COVID-19 pandemic: The experience in Taipei City Hospital, Taiwan. J. Dent. Sci. 15, 369-372 (2020).

19.Alharbi, A., Alharbi, S. \& Alqaidi, S. Guidelines for dental care provision during the COVID-19 pandemic. Saudi Dent. J. 32, 181-186 (2020).

20. Spicciarelli, V. et al. Prevention and safety in the dental office after Novel Human Coronavirus outbreak: unresolved questions and future directions. J. Osseointegration 12 , 145-153 (2020).

21.Bhanushali, P. et al. COVID-19: Changing Trends and Its Impact on Future of Dentistry. Int. J. Dent. 2020, (2020).

22. Muktawat, K. Dental clinic management in between / after COVID-19 Pandemic. 6, 3138 (2020).

23.Peng, X. et al. Transmission routes of 2019$n C o V$ and controls in dental practice. Int. J. Oral Sci. 12, 1-6 (2020).

24. Amato, A. et al. Infection control in dental practice during the covid-19 pandemic. Int. J. Environ. Res. Public Health 17, 1-12 (2020).

25. Koticha, P. B. et al. COVID-19 in children: its impact on oral health and paediatric dentistry. Int. J. Sci. Healthc. Res. 5, 377389 (2020).

26.Gurzawska-Comis, K., Becker, K., Brunello, G., Gurzawska, A. \& Schwarz, F. Recommendations for Dental Care during COVID-19 Pandemic. J. Clin. Med. 9, 1833 (2020).

27.Meng, L., Hua, F. \& Bian, Z. Coronavirus Disease 2019 (COVID-19): Emerging and Future Challenges for Dental and Oral Medicine. J. Dent. Res. 99, 481-487 (2020).

28. Banakar, M. et al. COVID-19 transmission risk and protective protocols in dentistry: $A$ systematic review. BMC Oral Health 20, 112 (2020).

29.Bizzoca, M. E., Campisi, G. \& Muzio, L. Lo. Covid-19 pandemic: What changes for dentists and oral medicine experts? A narrative review and novel approaches to infection containment. Int. J. Environ. Res. 
Public Health 17, (2020).

30.Lucaciu, O., Tarczali, D. \& Petrescu, N. Oral healthcare during the COVID-19 pandemic. J. Dent. Sci. 10-13 (2020) doi:10.1016/j.jds.2020.04.012.

31.Sivaraman, K., Chopra, A., Narayana, A. \& Radhakrishnan, R. A. A five-step risk management process for geriatric dental practice during SARS-CoV-2 pandemic. Gerodontology $\quad 1-10 \quad$ (2020) doi:10.1111/ger.12499.

32. Volgenant, C. M. C., Persoon, I. F., de Ruijter, R. A. G. \& de Soet, J. J. Infection control in dental health care during and after the SARS-CoV-2 outbreak. Oral Dis. 1-10 (2020) doi:10.1111/odi.13408.

33.Kampf, G., Todt, D., Pfaender, S. \& Steinmann, E. Persistence of coronaviruses on inanimate surfaces and their inactivation with biocidal agents. J. Hosp. Infect. 104, 246-251 (2020).

34. Molin, K.D., Loo, C., Kazemi, R.B., Weinsten, G. The Practice of dentistry amidst the COVID-19 pandemic. Clinical Dentistry Reviewed 5, 1-15 (2021)

35. Omura, A., Omura, M. Dental Care during the Coronavirus Disease 2019 (COVID-19) Pandemic: Preventing Oral Frailty and COVID-19 Infection. COVID-19 Pandemic: Case Studies \& Opinions 02(02): 223-225 (2021)

36. Morley, J.E. Editorial: Oral Frailty. The journal of nutrition, health \& aging 24: 683684 (2020) 